\section{Biblioteket mangler en bok}

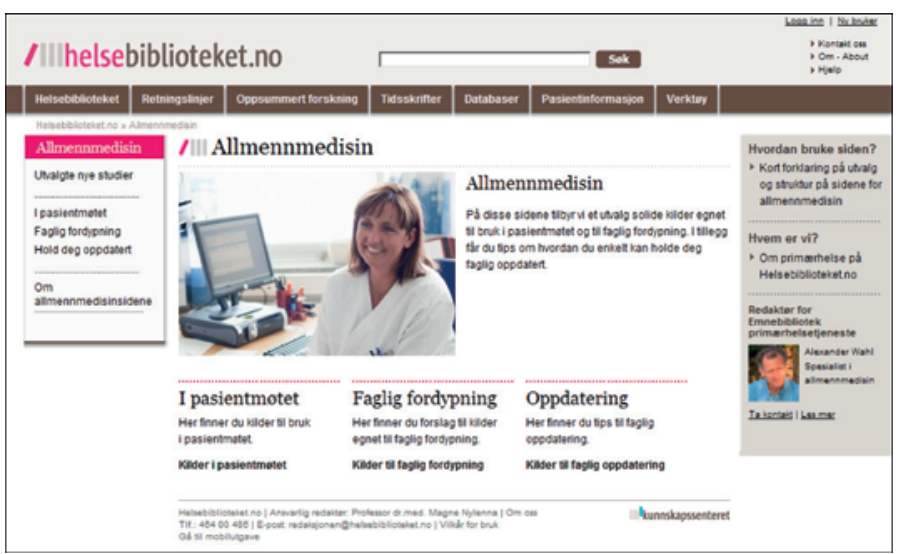

Emnebiblioteket for allmennmedisin er en del av Helsebiblioteket og har eksistert i halvannet år. Det er en samling lenker og ressurser som skal hjelpe klinikeren i det daglige. Redaktør er spesialist i allmennmedisin Alexander Wahl, og han har med seg en referansegruppe av solide allmennleger.

Siden er enkelt bygd opp med tre hovedinndelinger: I pasientmøtet, Faglig fordypning og Oppdatering. Det er også lenker til utvalgte artikler som er relevante for allmennmedisin.

Førsteinntrykket er bra: Det er direkte lenker til UpToDate og BMJ Best Practice, begge glimrende kliniske oppslagsverk som vi har gratis tilgang til takket være Helsebiblioteket. Det er lenker til norske ressurser som antibiotikaveilederen, brukerhåndbok i medisinsk biokjemi og Helsebibliotekets legemiddelsøk, som i ett og samme søk gir treff i både Felleskatalogen, interaksjonsdatabasen Drug Information Database (DRUID) og artikler i RELIS (Regionalt legemiddelinformasjonssenter). Meget nyttig!

Videre er det lenker til skåringsverktøy og tester, retningslinjer og veiledere og pasientinformasjon (oversatt fra BMJ Best Practice). Man finner McMasters pyramidesøk, ulike databaser med oppsummert forskning og lenker til RSS og e-posttjenester med oppdatert informasjon.

Så langt alt vel. Over til manglene.

Emnebiblioteket gir inntrykk av å være halvferdig, og plasseringen av stoffet synes litt tilfeldig. Som eksempel kan jeg nevne at Veileder i generell pediatri står som en av tre norske kilder under I pasientmøtet, mens andre liknende veiledere ligger under Faglig fordypning, uten at denne anmelderen klarer å forstå logikken.

Under I pasientmøtet er det en meget kort liste ( 9 stk.) over tester og skåringsverktøy. Der finner man The Hospital Anxiety And Depression Scale (HAD), men ikke Montgomery And Åsberg Depression Rating Scale (MADRS), som er den vanlige i allmennpraksis. Man finner Glasgow Coma Scale (GCS), men ikke Body Mass Index (BMI) og svangerskapskalkulator. Men så, under Øvrige, er det lenker til alle tester og kalkulatorer i UpToDate. Det er jo fint, men en snodig måte å gjøre det på. Og siden de fleste av verktøyene er mest egnet for sykehusmedisin, ville det vært greit om redaksjonen plukket ut de mest relevante og la inn en direkte lenke til dem.

Nyttige ressurser for pasienter, f.eks. Fritt sykehusvalg og fastlegen.no, ligger under Faglig fordypning, ikke under I pasientmøtet, som ville vært mer logisk.
Helsebiblioteket

Allmennlegesiden på Helsebiblioteket.no

http://helsebiblioteket.no/Allmennmedisin

Jeg skal ikke pirke på flere detaljer, men dette skulle illustrere at systematikken og logikken ikke er så god som den virket ved første øyekast.

Og så er det elefanten i rommet, rettere sagt det elefantformede hullet i Helsebibliotekets univers: Det oppslagsverket som de aller fleste allmennlegene bruker i det daglige, og som i realiteten er en metodebok for allmennmedisin, er knapt nok nevnt på Emnebiblioteket for allmennmedisin. Jeg snakker selvfølgelig om NEL Norsk elektronisk legehåndbok.

Jeg trodde først de hadde glemt hele NEL, men fant den til slutt. Den er omtalt med fem linjer under avsnittet Kvalitetsverktøy på allmennlegekontoret, sammen med Maturity Matrix og TrinnVis. Men NEL er ikke et kvalitetsverktøy, den er en klinisk håndbok. Hadde bibliotekaren en liten absens da han skulle plassere den, eller kan det være andre grunner?

Litt historie: I 2007 kjøpte Helsebiblioteket tilgang til NEL for norsk helsepersonell. Den ble da beskrevet som et godt og nyttig oppslagsverk i en travel hverdag, og redaktør Magne Nylenna sa at han ville arbeide for at flere $\mathrm{i}$ helsevesenet skulle ta den i bruk. Tre år senere snudde Helsebiblioteket tvert om og sa opp avtalen med NEL, til store protester fra allmennlegekorpset. Jeg skal ikke gå inn på diskusjonen her, men den ble ganske betent, og mange allmennleger følte at det gikk prestisje i saken fra Helsebibliotekets side. Når man ser hvor stemoderlig NEL behandles på Helsebibliotekets nettsider, kan man lure på om det er noe i det.

Det er selvfølgelig opp til Helsebiblioteket å velge hvilke kilder de vil kjøpe tilgang til, og hva de vil henvise til på sidene sine. Men det er påfallende at et redskap som er så viktig for så mange, både leger og studenter, gjemmes bort i en mørk krok. Enda mer underlig er det at Pasienthåndboka.no, hvor NELs store samling av utmerket pasientinformasjon er fritt tilgjengelig på nettet, ikke er nevnt med et ord.

Emnebiblioteket for allmennmedisin er greit nok. Men det virker uferdig og usystematisk, og jeg tviler på at det vil bli en sentral del av allmennlegenes hverdag i sin nåværende form.

Pernille Nylehn

Rehabilitering Vest

Haugesund 